\title{
The response of rats to long-term feeding with diets containing oxidized fat. 1 . Thermooxidative changes in fat, body weight gain, feed consumption and utilisation ${ }^{*}$
}

\section{Z. Zduńczyk ${ }^{1}$, J. Juśkiewicz', M. Dlugoszewska', S. Frejnagel and A. Koncicki ${ }^{2}$}

IInstitute of Animal Reproduction and Food Research, Division of Food Science, Polish Academy of Sciences Tuwima 10, 10-747 Olsztyn, Poland

${ }^{2}$ Faculty of Veterinary Medicine, Warmian and Mazurian University in Olsztyn Oczapowskiego 13, 10-957 Olsztyn, Poland

(Received 11 June 1999; accepted 13 January 2000)

\begin{abstract}
A 5:3:2 mixture of rape seed oil, poultry fat, and beef tallow was saturated with oxygen and heated at $70-80^{\circ} \mathrm{C}$ for 48 to $96 \mathrm{~h}$ to obtain batches of fat having peroxide values of $5.1,50.0,100.5$, and $208.6 \mathrm{meq} \mathrm{O}_{2} / \mathrm{kg}$ and respective anisidine values of 2.6, 12.1,22.2, and 95.9. Six casein diets containing $10 \%$ oxidized fat with peroxide values of $5,40,80,120,160$ or 200 meq $\mathrm{O}_{2} / \mathrm{kg}$ were prepared and fed for 8 wecks each to 12 individually housed rats with an initial body weight of 58.5 g. Body weight gain, feed intake and utilisation, PER, protein and fat digestibilities, VFA content in the caecum of two groups of rats, and $\beta$-glucuronidase activity in the caecal digesta, and phosphatase activity in the mucosa of the small intestine were measured.

The degree to which fat was oxidized did not affect feed intake, body weight gain or protein digestibility. Feed utilisation was, however, lower in the groups fed diets with peroxide values of 160 and $200 \mathrm{meq} \mathrm{O}_{2} / \mathrm{kg}$. Fat digestibility was lower only with the highest degree of oxidation. Phosphatase activity decreased while that of glucuronidase rose as the degree of fat oxidation increased. The VFA concentration in the digesta of the caecum of rats fed the diet with the most oxidized fat was significantly lower than in the control group, which points to the unfavourable effect of oxidized fat on bacterial activity in the large intestine.
\end{abstract}

KEY WORDS: rats, lipid peroxidation, growth, digestibility, feed efficiency, enzymes, VFA, caccum

* Supported by the State Committee for Scientific Research, Grant No 5 PO6E 02013 


\section{INTRODUCTION}

The component of feeds and food that is most susceptible to oxidation is fats. Numerous studies have provided much evidence for the very harmful effects of prolonged heating of fats (for instance, during frying) leading to the formation of polymerized and cyclic products (Corcos Benedetti et al., 1987; Lopez-Varela et al., 1995; Sanchez-Muniz et al., 1998). There is less information, however, on the negative effects of oxidizing fat at lower temperatures, e.g. as when fat is stored improperly or heated for short time during the production of meat meal. Earlier experiments of many authors have provided conflicting results on the nutritional and toxic effects of oxidized fat on animals (Carpenter et al., 1966). According to more recent experiments of Hochgraf et al. (1997), a 10\% content of fat oxidized to $1300 \mathrm{meq} \mathrm{O}_{2} / \mathrm{kg}$ at a temperature of $37^{\circ} \mathrm{C}$ caused the growth rate of rats to decline mainly as a consequence of lower feed intake, but at equal intakes, differences in body weight of rats fed on fresh and oxidized fat were not significant. Hayam et al. (1993) reported contradictory results and did not find differences in feed intake and oil digestibility, but did find significant differences in the body weight between rats fed diets containing soyabean oil fresh or oxidized to 420 meq $\mathrm{O}_{2} / \mathrm{kg}$.

Similar results were obtained by Sanchez-Muniz et al. (1998) who found that at similar feed intake weight gains were smaller in rats fed highly oxidized than fresh soya oil. According to the authors the lower growth rate was caused by the smaller linolenic acid content in oxidized oil. The diversity of the results of reported experiments justifies the further studies.

The objective of this study was to investigate the effect of feeding thermooxidized fats on the intake and utilisation of feed, growth of animals, and selected indicators of gastrointestinal tract function of rats (fat and protein digestibilities, activity of selected enzymes, large intestine microflora). A mixture of fats applied in animal nutrition was used; oxidation was conducted under conditions of intestive oxygen access similar to those found in fat-supplemented feed mixtures.

\section{MATERIAL AND METHODS}

Animals and diets

Seventy-two male Wistar rats with body weights of $58.6 \pm 3.1 \mathrm{~g}$, housed under standard conditions $\left(21-22^{\circ} \mathrm{C}\right.$, relative humidity $\left.50-70 \%\right)$ were used in this experiment. The rats were divided into 6 groups of 12 each and were fed for 8 weeks with casein diets containing $10 \%$ fat oxidized to various degrees (Table 1). 
TABLE 1

Composition of diets

\begin{tabular}{lc}
\hline Component & $\%$ \\
\hline Casein & 14.8 \\
DL-methionine & 0.2 \\
Mineral mixture (NRC, 1976) & 3.0 \\
Vitamin mixture (AOAC, 1975) & 1.0 \\
Potato starch & 10.0 \\
Maize starch & 61.0 \\
Fat (rapeseed oil, poultry fat and beef tallow, 50:30:20) & 10.0 \\
\hline
\end{tabular}

1 mineral mixture containing in $100 \mathrm{~g}: 73.5 \mathrm{~g} \mathrm{CaHPO}_{4} ; 8.10 \mathrm{~g} \mathrm{~K}_{2} \mathrm{HPO}_{4} ; 6.80 \mathrm{~g} \mathrm{~K}_{2} \mathrm{SO}_{4} ; 3.06 \mathrm{~g} \mathrm{NaCl}$; $2.10 \mathrm{~g} \mathrm{CaCO}_{3} ; 2.14 \mathrm{~g} \mathrm{NaHPO}_{4} ; 2.50 \mathrm{~g} \mathrm{MgO}^{2} 558 \mathrm{mg}$ ferric citrate; $81 \mathrm{mg} \mathrm{ZnCO} ; 421 \mathrm{mg} \mathrm{MnCO}_{3}$; $33.3 \mathrm{mg} \mathrm{CuCO} ; 0.7 \mathrm{mg} \mathrm{KJ}$ and $705 \mathrm{mg}$ citric acid

${ }^{2}$ vitamin mixture containing in $1 \mathrm{~g}: 2000 \mathrm{IU}$ vitamin $\mathrm{A} ; 200 \mathrm{IU}$ vitamin $\mathrm{D}_{3} ; 10 \mathrm{IU}$ vitamin $\mathrm{E} ; 0.5 \mathrm{mg}$ vitamin $\mathrm{K} ; 200 \mathrm{mg}$ choline; $10 \mathrm{mg}$ p-aminobenzoic acid; $10 \mathrm{mg}$ inositol; $4 \mathrm{mg}$ niacin; $4 \mathrm{mg}$ calcium pantothenate; $0.8 \mathrm{mg}$ riboflavin; $0.5 \mathrm{mg}$ thiamin; $0.5 \mathrm{mg}$ pyridoxine; $0.2 \mathrm{mg}$ folic acid; 0.04 mg biotin; $0.003 \mathrm{mg}$ cobalamin; sucrose (supplement to $1 \mathrm{~g}$ )

${ }^{3}$ diets for groups I-VI were supplemented with the fat mixture of different peroxide valucs: 5,40 , 80,120160 and $200 \mathrm{meq} \mathrm{O}_{2} / \mathrm{kg}$, respectively

The diets contained about $13 \%$ crude protein. The amount of energy from particular dietary components (protein, 12\%; carbohydrates, $48 \%$; fat $40 \%$ ) was similar to the Western-type diet (Dabai et al., 1996).

\section{Preparation of fat}

A mixture composed of rape seed oil (50\%), poultry fat (30\%), and beef tallow $(20 \%)$ was saturated with oxygen and intensively aerated while heating at $70-80^{\circ} \mathrm{C}$ for 48 to $96 \mathrm{~h}$. The degree of oxidation was monitored twice daily by determining the peroxidation value expressed in miliequivalents of oxygen per $\mathrm{kg}$ of fat (meq $\mathrm{O}_{2} / \mathrm{kg}$ ). Batches of fat in which the peroxidation value exceeded 50 , 100 and $200 \mathrm{meq} \mathrm{O}_{2} / \mathrm{kg}$ were used for the experiment. The fat was stored at $4^{\circ} \mathrm{C}$. The diets were prepared weekly. Fat with the required peroxidation value $(5,40$, $80,120,160$ i $200 \mathrm{meq} \mathrm{O}_{2} / \mathrm{kg}$ ) was obtained by mixing fats of various degrees of oxidation in the appropriate proportions.

\section{Feeding experiments}

Feed intake, body weight gains, and feed utilisation ratio were computed for the first (weeks 1-4) and second (weeks 5-8) periods of the experiment. The protein utilisation ratio (PER) was calculated for the first period. In the fourth week of 
the experiment faeces were collected to determine protein and fat digestibilities. The true digestibility of protein was computed adjusting for metabolic nitrogen according to Rakowska et al. (1978). After the experiment was completed the rats were anaesthetized with urethane (Sigma) and the first segment of the small intestine and the caecum with digesta were sampled.

\section{Analytical methods}

The degree of fat oxidation was assessed on the basis of peroxide, acid, and anisidine values. The peroxide was determined according to AOAC (1990), the acid value (AN) according to Pr MN-ISO 660 (1996), and the anisidine value according to ISO 6885 (1988). Alkaline phosphatase (AP) activity in the mucosa of the small intestine was determined in a homogenate prepared according to Franson et al. (1985) using a diagnostic kit from Alpha Diagnostics. $\beta$-glucuronidase acitivty in the large intestine digesta was determined by a modified version of the method by Andrieux et al. (1992) with an enzyme standard and 4-nitrophenyl- $\beta$ D-glucuronide as the substrate. The VFA content in the caecum of rats (from the control and VI group) was determined by gas chromatography (Ziołecki and Kwiatkowska, 1973), fatty acids were separated and quantified by GLC on a Pye Unicam 104 model gas chromatograph with a flame ionisation detector.

The results were subjected to statistical analysis using one-way analysis of variance and Duncan's multiple range test.

\section{RESULTS AND DISCUSSION}

The characteristics of fats oxidized to various degrees are presented in Table 2. Oxidation at $70-80^{\circ} \mathrm{C}$ caused a rapid increase in primary oxidation products (lipid peroxides) and a slower increase in secondary products (aldehydes, ketones, and others). This is indicated by the peroxide values ( 5 to $200 \mathrm{meq} \mathrm{O} / \mathrm{kg}$ ) that is many times higher than the anisidine values (2.6 to 95.9). An inverse proportion of peroxide and anisidine values is found in fats subjected to intensive heating without additional aeration. In the experiment of Tynek and Drozdowski (1998) after 4.5 and $45 \mathrm{~h}$ of frying fat, the respective peroxide values were 8.9 and $5.4 \mathrm{meq} \mathrm{O}_{2} / \mathrm{kg}$, while the anisidine values were 113.7 and 167.9 , respectively. In these conditions, the formation of polymers is accompanied by distinct losses in unsaturated fats (Corcos Benedetti, 1987). In our experiments, we did not find significant changes in the composition of fatty acids as the result of oxidizing fat (Table 2). The tendency towards a reduction in the proportion of $\mathrm{C}_{18: 3}$ and $\mathrm{C}_{18: 2}$ acids, and rise in $\mathrm{C}_{18: 1}$ and $\mathrm{C}_{18: 0}$ acids was similar to the results of 
other authors (Yoshida and Kajimoto, 1989; Hayam et al., 1993; Hochgraf et al., 1997), who oxidized fat under similar conditions. Batches of fat prepared for the experiment differed the most in terms of their peroxide contents, to a lesser degree in their contents of secondary oxidation products, and did not differ at all in their fatty acid composition (Table 2).

TABLE 2

Characteristics of fat with the different degree of thermooxidative transformation

\begin{tabular}{lrrrr}
\hline & \multicolumn{4}{c}{ Fat } \\
\cline { 2 - 5 } & Initial & LOO-50 & LOO-100 & LOO-200 \\
\hline Indices' & & & & \\
$\quad$ peroxide value, meq $\mathrm{O}_{2} / \mathrm{kg}$ & 5.1 & 50.0 & 100.5 & 208.6 \\
$\quad$ acid value, mg KOH/g & 2.30 & 2.89 & 3.11 & 4.40 \\
$\quad$ anisidine value & 2.63 & 12.13 & 22.18 & 95.92 \\
& & & & \\
Composition of fatty acids ${ }^{2} \%$ & & & & \\
$<\mathrm{C}_{16}$ & 1.82 & 1.89 & 1.84 & 1.89 \\
$\mathrm{C}_{16: 0}$ & 14.90 & 13.46 & 13.70 & 14.12 \\
$\mathrm{C}_{16: 1}$ & 3.08 & 2.55 & 2.52 & 2.53 \\
$\mathrm{C}_{17: 0}$ & 0.59 & 0.65 & 0.61 & 0.62 \\
$\mathrm{C}_{17: 1}$ & 0.45 & 0.47 & 0.39 & 0.39 \\
$\mathrm{C}_{18: 0}$ & 7.88 & 7.93 & 8.03 & 8.29 \\
$\mathrm{C}_{18: 1}$ & 45.66 & 48.98 & 49.40 & 49.92 \\
$\mathrm{C}_{18: 2}$ & 16.12 & 14.26 & 13.89 & 13.08 \\
$\mathrm{C}_{18: 3}$ & 5.19 & 5.23 & 4.95 & 4.37 \\
$<\mathrm{C}_{18}$ & 4.31 & 4.58 & 4.67 & 4.79 \\
& & & & \\
$\sum$ saturated acids & 25.37 & 24.20 & 24.62 & 25.54 \\
$\sum$ unsaturated acids & 74.63 & 75.80 & 75.38 & 74.46 \\
\hline
\end{tabular}

1 means of threc determinations

${ }^{2}$ means of duplicate analyses

The various degrees of oxidation of fat in the diets did not cause significant differences in protein digestibility (Table 3), which ranged from 92.5 to $94.1 \%$ and corresponded with the values given by Eggum (1973) for casein diets. Significant lowering $(\mathrm{P}<0.05)$ was found, however, of the apparent digestibility of fat with the highest peroxide value $\left(200 \mathrm{meq} \mathrm{O}_{2} / \mathrm{kg}\right)$ in comparison with the control group: 96.9 vs $97.8 \%$. A much larger decline in fat digestibility was found by Corcos Benedetti (1987) in rats fed a diet containing a high proportion (over $70 \%$ total fat) of oxidized and polymerized soyabean oil fraction (98 vs $68 \%)$. 
TABLE 3

Ether extract and crude protein digestibility', \%

\begin{tabular}{lllllllll}
\hline & \multicolumn{9}{c}{ Group $^{2}$} & \multirow{2}{*}{ SEM } \\
\cline { 2 - 6 } & \multicolumn{1}{c}{ I } & II & III & IV & V & VI \\
\hline Crude protein & 92.5 & 93.7 & 93.6 & 94.1 & 93.9 & 94.1 & 0.135 \\
Ether extract & $97.8^{\mathrm{a}}$ & $97.4^{\text {ab }}$ & $97.3^{\text {ab }}$ & $97.1^{\text {ab }}$ & $97.3^{\text {ab }}$ & $96.9^{\mathrm{b}}$ & 0.106 \\
\hline
\end{tabular}

1 values represent means and standard error of the mean (SEM), $n=12$

2 peroxide value of dietary fa! for group I to VI was: below $5,40,80,120,160$ and $200 \mathrm{meq} \mathrm{O}_{2} / \mathrm{kg}$, respectively

a. b $-\mathrm{P}<0.05$

TABLE 4

Alkaline phosphatase (AP) activity in the small intestine and $\beta$-glucuronidase ( $\beta$-gluc) activity in the caecal digesta ${ }^{1}$

\begin{tabular}{lccccccc}
\hline & \multicolumn{9}{c}{ Group $^{2}$} & \multicolumn{2}{c}{ SEM } \\
\cline { 2 - 7 } & I & II & III & IV & V & VI & \\
\hline AP, U/g & 60.5 & 51.1 & 55.2 & 50.6 & 51.9 & 50.8 & 2.326 \\
$\beta-$ gluc, U/g & 0.48 & 0.48 & 0.55 & 0.64 & 0.64 & 0.65 & 0.027 \\
\hline
\end{tabular}

' values represent means and standard error of the mean (SEM), $n=12$

${ }^{2}$ peroxide value of dietary fat for group I to VI was: below $5,40,80,120,160$ and $200 \mathrm{meq} \mathrm{O}_{2} / \mathrm{kg}$, respectively

The presence of peroxides from oxidized fat caused the alkaline phosphatase activity (AP) in the mucosa of the small intestine (Table 4) to decline from $60.5 \mathrm{U} / \mathrm{g}$ in the control group to 50.6-55.2 $\mathrm{U} / \mathrm{g}$ in the experimental groups, although the change was not significant statistically. The lower activity of this enzyme (which affects the absorptive functions of the intestinal mucosa) corresponded with the lower digestibility of fat in group VI, in which rats received fat with a peroxide value of $200 \mathrm{meq} \mathrm{O}_{2} / \mathrm{kg}$.

The activity of $\beta$-glucuronidase in the caecal digesta increased from $0.48 \mathrm{U} / \mathrm{g}$ in the control group to $0.65 \mathrm{U} / \mathrm{g}$ in group VI (nonsignificant difference). This may indicate that the oxidized fat caused unfavourable changes in the composition of the microflora of the large intestine. The increased activity of $\beta$-glucuronidase that occurs, among others, when the fat content of the diet is increased (Manoj et al., 1993), can cause the cellulolytic activity of large intestine microflora to decline (Indira et al., 1980). This suggestion is corroborated by the difference of short-chain fatty acids content in the caecal digesta of rats fed diets 
Sum and composition of volatile fatty acids in the caecal content

\begin{tabular}{|c|c|c|c|}
\hline & \multicolumn{2}{|c|}{ Group $^{2}$} & \multirow[t]{2}{*}{ SEM } \\
\hline & I & Vl & \\
\hline Sum $\mathrm{C}_{2}-\mathrm{C}_{5}, \mathrm{mmol} / 100 \mathrm{~g}$ caecal content & $12.10^{\wedge}$ & $8.75^{\mathrm{B}}$ & 0.358 \\
\hline $\mathrm{C}_{2}, \%$ of the sum & 59.66 & 57.63 & \\
\hline $\mathrm{C}_{3}, \%$ of the sum & 24.63 & 22.33 & \\
\hline $\mathrm{C}_{4}, \%$ of the sum & 11.13 & 13.08 & \\
\hline $\mathrm{C}_{s}, \%$ of the sum & 4.68 & 6.97 & \\
\hline
\end{tabular}

' values represent means and standard error of the mean (SEM), $n=12$

${ }^{2}$ peroxide value of dietary fat for group I to VI groups was below 5 and $200 \mathrm{meq} \mathrm{O}_{2} / \mathrm{kg}$, respectively

A.B $-\mathrm{P}<0.01$

differing most in degree of fat oxidation (groups I and VI). The use of highly oxidized fat in the diet reduced the sum of volatile fatty acids $\left(\mathrm{C}_{2}-\mathrm{C}_{5}\right)$ in comparison with the group receiving non-oxidized fat (Table 5). The oxidized fat caused an approximately $2 \%$ reduction in the proportion of acetic and propionic acids in the sum of total short-chain fatty acids, and similar increase of the proportion of butyric and valeric acids.

Adding highly oxidized fat to the diet did not cause a reduction in feed intake (Table 6). Other investigators have obtained different results using polymerized soyabean oil (Corcos Benedetti et al., 1987) or oil oxidized to $1300 \mathrm{meq} \mathrm{O} / \mathrm{kg}$ (Hochgraf et al., 1997). In our experiment, when fat with a low peroxide value was replaced with one having higher number $\left(160\right.$ and $200 \mathrm{meq} \mathrm{O}_{2} / \mathrm{kg}$ ) we found a reduction in PER from 3.08 to 2.96 and 2.98, respectively. In the first 4 weeks of the experiment FER was also significantly reduced in groups V and VI, but in the second period of the experiment this ratio did not differ. Throughout the whole experiment, FER was higher in group $\mathrm{V}$.

Hayam et al. (1995) reported poorer feed utilisation in a 7-week experiment on rats fed fat oxidized to $420 \mathrm{meq} \mathrm{O}_{2} / \mathrm{kg}$. Also in an experiment by SanchezMuniz et al. (1998) the addition of $15 \%$ highly oxidized sunflower oil, which had four times more of the polar fraction than non-oxidized oil, to the diets of rats did not affect feed consumption although a significant decline in body weight gain, poorer feed utilisation, and lowering of PER were noted. In the experiments of the authors cited above mainly secondary products of fat oxidation, including polymers of fatty acids, had a negative effect on feed consumption and utilisation. 
TABLE 6

Diet intake, body weight gain, protein efficiency ratio (PER) and feed efficiency ratio (FER)'

\begin{tabular}{|c|c|c|c|c|c|c|c|}
\hline & \multicolumn{6}{|c|}{ Group $^{2}$} & \multirow[t]{2}{*}{ SEM } \\
\hline & I & II & III & IV & V & VI & \\
\hline \multicolumn{8}{|l|}{ Diet intake, $g$} \\
\hline during 4 weeks & 311.8 & 308.3 & 312.4 & 317.2 & 311.6 & 311.3 & 1.313 \\
\hline during 8 weeks & 705.3 & 715.8 & 721.5 & 725.3 & 718.4 & 715.6 & 2.599 \\
\hline \multicolumn{8}{|l|}{ Rat body weight, $g$} \\
\hline initial & 58.6 & 58.5 & 58.6 & 58.6 & 58.6 & 58.5 & 0.307 \\
\hline after 4 weeks & 184.7 & 182.5 & 183.1 & 185.8 & 179.3 & 180.4 & 0.799 \\
\hline after 8 weeks & $259.4^{\mathrm{ab}}$ & $264.9^{\mathrm{a}}$ & $260.2^{\mathrm{ab}}$ & $261.3^{\mathrm{ab}}$ & $254.0^{\mathrm{b}}$ & $258.3^{\mathrm{ab}}$ & 1.388 \\
\hline \multicolumn{8}{|l|}{ Body weight gain, g } \\
\hline during 4 weeks & 126.1 & 123.7 & 124.4 & 127.7 & 121.4 & 122.2 & 0.753 \\
\hline during 8 weeks & 200.6 & 205.8 & 201.4 & 203.2 & 194.9 & 200.7 & 1.364 \\
\hline PER, 1.4 weeks, g/g & $3.08^{\mathrm{a}}$ & $3.05^{\mathrm{ab}}$ & $3.02^{\mathrm{ab}}$ & $3.04^{\mathrm{ab}}$ & $2.96^{\mathrm{b}}$ & $2.98^{b}$ & 0.012 \\
\hline FER, 1-4 weeks, g/g & $2.47^{a}$ & $2.49^{: \mathrm{b}}$ & $2.51^{\mathrm{ab}}$ & $2.48^{\mathrm{ab}}$ & $2.57^{\mathrm{b}}$ & $2.55^{\mathrm{b}}$ & 0.010 \\
\hline FER, $5-8$ weeks, g/g & 5.35 & 5.04 & 5.21 & 5.35 & 5.40 & 5.41 & 0.069 \\
\hline FER, $1-8$ weeks, g/g & $3.5 \mathrm{I}^{: \mathrm{b}}$ & $3.47^{i}$ & $3.55^{\mathrm{ab}}$ & $3.57^{\mathrm{ab}}$ & $3.63^{\mathrm{ab}}$ & $3.56^{\mathrm{ab}}$ & 0.019 \\
\hline
\end{tabular}

1 values represent means and standard error of the mean (SEM), $\mathrm{n}=12$

2 peroxide value of dietary fat for group I to VI groups was: below 5, 40, 80, 120, 160 and $200 \mathrm{meq} \mathrm{O}_{2} / \mathrm{kg}$, respectively

$\mathrm{a}, \mathrm{b}-\mathrm{P}<0.05$

\section{CONCLUSIONS}

The thermooxidative changes in fats occurring under conditions of intensive oxygen access were mainly a rapid rise in the primary products of oxidation (expressed as the peroxide value) and slower increase in secondary oxidation products (anisidine value). Oxidized fat did not reduce feed intake, body weight gain, or protein digestibility. A significant reduction in the digestibility of fat occurred only in the group receiving the most oxidized fat $\left(200\right.$ meq $\left.\mathrm{O}_{2} / \mathrm{kg}\right)$ and corresponded with a reduction in phosphatase activity in the small intestine of rats in this group. A rise in the activity of $\beta$-glucuronidase and lowering of the concentration of volatile fatty acids in the digesta of the caecum indicates that a high level of products of fat oxidation in the diets had an adverse effect on the activity of the microflora of the large intestine. The use of highly oxidized fats (160 and $200 \mathrm{meq}$ $\mathrm{O}_{2} / \mathrm{kg}$ ) worsened feed utilisation in the first 4 weeks of the experiment. 


\section{REFERENCES}

Andrieux C., Pacheco E.D., Bouchet B., Gallant D., Szylit O., 1992. Contribution of the digestive tract microflora to amylomaize starch degradation in the rat. Brit. J. Nutr. 67, 489-499

AOAC, 1990. Official Methods of Analysis of the Association of Official Analytical Chemists,. 15th Edition, Arlington

Carpenter K.J., L'Estrange J.K., Lca C.H., 1966. Effects of moderate levels of oxidized fat in animal diets under controlled conditions. Proc. Nutr. Soc. 25, 25-31

Corcos Benedetti P.C., D’Aquino M., Di Felice M., Gentili V., Tagliamonte B., Tomassi G., 1987. Effects of a fraction of thermally oxidized soy bean oil on growing rats. Nutr. Rep. Int. 36, $387-401$

Dabai F.D., Walker A.F., Sambrook 1.E., Welch V.A., Owen R.W., 1996. Comparative effect on blood lipids and faccal steroids of five legume species incorporated into a semi-purified, hypercholesterolaemic rat diet. Brit. J. Nutr. 75. 557-571

Eggum B.O., 1973. A study of certain factors influencing protein utilization in rats and pigs. Report no 406. National Institute of Animal Science, Copenhagen, pp.173

Franson J.C., Murray H.C., Bunck C., 1985. Enzyme activities in plasma, kidney, liver, and muscle of five avian species. J. Wildlife Dis. 21, 33-39

Hayam I., Cogan U., Mokady S., 1993. Dietary oxidized oil enhance the activity of $\left(\mathrm{Na}^{+} \mathrm{K}^{+}\right)$ATPase and acetylcholinesterase and lowers the fluidity of rats erythrocyte membrane. J. Nutr. Biochem. $4,563-568$

Hayam I., Cogan U., Mokady S., 1995. Dietary oxidized oil and the activity of antioxidant enzymes and lipoprotein peroxidation in rats. Nutr. Res. 15, 1037-1044

Hochgraf E., Mokady S., Cogan U., 1997. Dietary oxidized linoleic acid modifies lipid composition of rat liver microsomes and increases their fluidity. J. Nutr. 127, 681-686

Indira M., Vijayammal P.L., Menon P.V.G., Krup P.A., 1980. Effect of dietary fibre on intestinal bacterial $\beta$-glucuronidase activity in chicken fed a cholesterol-containing diet. Cancer, 46 , 2430-2432

Lopez-Varela S., Sanchez-Muniz F.J., Cuesta C., 1995. Decreased food efficiency ratio, growth retardation and changes in liver composition in rats consuming thermoxidized and polymerized sunflower oil used for frying. Food Chem. Toxicol. 33, 181-189

Manoj G., Harikumaran Thampi B.S., Leelamma S., Menon V.P., 1993. Dietary fiber and activity of intestinal tissue $\beta$-glucuronidase in rats. Nutr. Res. 13, 575-582

Rakowska M., Szkiłłądziowa W., Kunachowicz H., 1978. Biological Value of Food Protein (in Polish). WNT, Warszawa.

Sanchez-Muniz F.J., Lopez-Verela S., Garrido-Polonio M.C., Cuesta C., 1998. Dietary effect on growth, liver peroxides, and serum lipoprotein lipids in rats fed a thermooxidised and polymerized sunflower oil. J. Sci. Food Agr. 76, 364-372

Tynek M., Drozdowski B., 1998. Monitoring of thermooxidative oils transformations by spectrophotometric method (in Polish). Żywność, Technologia, Jakość 4, 27-38

Yoshida H., Kajimoto G., 1989. Effect of dietary vitamin $E$ on the toxicity of autoxidized oil to rats. Ann. Nutr. Metab. 33, 153-161

Ziołecki A., Kwiatkowska E., 1973. Gas chromatography of $\mathrm{C}_{1}$ to $\mathrm{C}_{5}$ fatty acids in rumen fluid and fermentation media. J. Chromatogr. 80, 250-254 


\section{STRESZCZENIE}

Reakcja szczurów na dlugotrwale karmienie dietami zawierającymi utleniony thuszcz. 1. Ter-
mooksydatywne zmiany w tluszczu, przyrosty masy ciala, spożycie i wykorzystanie paszy

Mieszaninę oleju rzepakowego, tluszczu drobiowego i łoju wołowego (5:3:2) nasycano tlenem i ogrzewano w $70-80^{\circ} \mathrm{C}$ przez 48 do 96 godzin uzyskując partie tłuszczu o liczbie nadtlenkowej 5,1 ; 50,$0 ; 100,5$ i 208,6 meq $\mathrm{O}_{2} / \mathrm{kg}$ i liczbie anizydynowej odpowiednio 2,$6 ; 12,1 ; 22,2 ; \mathrm{i} 95$,9. Przygotowano sześć diet kazeinowych zawierających $10 \%$ utlenionego tłuszczu o liczbie nadtlenkowej 5 , $40,80,120,160$ i $200 \mathrm{meq} \mathrm{O}_{2} / \mathrm{kg}$ i każdą z nich podawano przez 8 tygodni 12 indywidualnie utrzymywanym szczurom o początkowej m.c. $58,5 \mathrm{~g}$. Oznaczano przyrosty masy ciała, pobranie i wykorzystanie paszy, PER, strawność białka i tłuszczu, zawartość LKT w jelicie ślepym u 2 grup szczurów, aktywność $\beta$-glukuronidazy w treści jelita ślepego oraz aktywność fosfatazy w nabłonku jelita cienkiego.

Stopień utlenienia tłuszczu nie miał wpływu na pobranie paszy, przyrosty m.c. oraz strawność białka. Wykorzystanie paszy było niższe w grupach żywionych dietami zawierającymi tłuszcz o liczbie nadtlenkowej 160 i $200 \mathrm{meq} \mathrm{O}_{2} / \mathrm{kg}$, zaś strawność tłuszczu obniżyła się jedynie przy najwyższym stopniu utlenienia. Ze wzrostem stopnia utlenienia tłuszczu zmniejszała się aktywność fosfatazy a zwiększała glukuronidazy. Zawartość LKT w treści jelita ślepego szczurów żywionych dietą zawierającą najbardziej utleniony tłuszcz była istotnie mniejsza niż $w$ grupie kontrolnej, co wskazuje na niekorzystny wpływ utlenionego tłuszczu na aktywność bakterii w jelicie grubym. 